Research Article

\title{
Chloride Ingress in Cement Mortars Exposed to Acidithiobacillus thiooxidans Bacteria
}

\author{
Onesmus Mulwa Munyao ${ }^{1},^{1}$ Joseph Karanja Thiong'o ${ }^{1},^{1}$ \\ Jackson Muthengia Wachira $\mathbb{D}^{2}{ }^{2}$ Daniel Karanja Mutitu, ${ }^{2}$ Genson Murithi, ${ }^{2}$ \\ and Romano Mwirichia ${ }^{3}$
}

${ }^{1}$ Department of Chemistry, Kenyatta University, Nairobi, Kenya
${ }^{2}$ Department of Physical Sciences, University of Embu, Embu, Kenya
${ }^{3}$ Department of Biological Sciences, University of Embu, Embu, Kenya

Correspondence should be addressed to Onesmus Mulwa Munyao; onesmusmulwa@gmail.com

Received 15 June 2020; Revised 10 November 2020; Accepted 13 November 2020; Published 24 November 2020

Academic Editor: Francesco Ruffino

Copyright (C) 2020 Onesmus Mulwa Munyao et al. This is an open access article distributed under the Creative Commons Attribution License, which permits unrestricted use, distribution, and reproduction in any medium, provided the original work is properly cited.

\begin{abstract}
Concrete structures placed in aggressive aqueous environments are vulnerable to degradation. Majority of studies have linked structural failures to the ingress of deleterious ions into the cement matrix. Some microbial activities may accelerate the penetration of harmful materials into the cement matrix and hence cause pronounced deterioration. This work reports a laboratory-simulated study carried out to determine the extent of chloride ingress in cement mortars exposed to Acidithiobacillus thiooxidans. Test prisms were cast from Portland pozzolana cement (PPC) and ordinary Portland cement (OPC) with water-tocement ratio maintained at 0.5 . Acidithiobacillus thiooxidans bacterial solution of concentration $1.0 \times 10^{7}$ cell $/ \mathrm{mL}$ was used to prepare microbial mortar prisms, whereas distilled water was used to prepare the control mortar prisms. The test prisms were subjected to porosity and accelerated chloride ingress after $28^{\text {th }}$ day of curing. Compressive strength was determined after the $2^{\text {nd }}$, $7^{\text {th }}, 28^{\text {th }}$, and $56^{\text {th }}$ days of curing. Apparent diffusion coefficients $\left(D_{\text {app }}\right)$ were estimated from the solutions to Fick's second law of diffusion. After the $56^{\text {th }}$ day of curing, the microbial-treated mortars exhibited a significant reduction in compressive strength. The resultant percentage decrease in compressive strength was $30.74 \%$ and $19.88 \%$ for OPC and PPC, respectively. Further, microbialtreated mortars demonstrated both high porosity and chloride ingress as compared to the control test mortars. Scanning electron microscopy (SEM) and X-ray diffraction (XRD) analyses showed the formation of new deleterious products in the microbialexposed mortars.
\end{abstract}

\section{Introduction}

Concrete is used in different environments for construction and placement of various structures. In marine settings, reinforced concrete is commonly used in putting up structures such as docks, harbors, and offshore platforms. This is attributed to the ability of concrete to endure severe naval surroundings [1]. Concrete stability is key in appraising the lifetime of cement-based structures [2]. One of the main durability threats of concrete has been attributed to chloride-induced corrosion of the rebar. Globally, billions of dollars are spent annually to repair and maintain structural failures related to chloride-induced corrosion [3].

Chloride ingress in cement-based materials is considered to be a major contributor to structural failures. However, microbial activities present in concrete placed in hostile setups such as sewage systems may trigger acceleration of damage on such structures. Microbial activity in sewer networks creates a corrosive environment through a process referred to as microbially induced concrete corrosion (MICC) [4-6]. According to Rigby, mineral and/or organic acids produced by the microbes deteriorate the concrete matrix [7]. This forms an appropriate conduit for the ingress 
of other deleterious materials such as chlorides, carbon dioxide, and sulphate ions into the cement matrix and hence compromise the structural integrity $[8,9]$.

Concrete pipes and manhole covers of sewage systems experience a severe attack by MICC. Olmstead and Hamlin reported the first case associated with MICC on the outfall sewer in Los Angeles [10]. Biodeterioration of concrete is associated with chemolithotrophic sulphur oxidizing bacteria of the genus Thiobacillus [11]. The metabolic activity of the Thiobacillus bacteria results in the production of biogenic sulphuric acid [12]. The successive reaction of the formed biogenic acid with the concrete constituents results in the formation of expansive and low strength products [13].

Gypsum $\left(\mathrm{CaSO}_{4} \quad 2 \mathrm{H}_{2} \mathrm{O}\right)$ and ettringite $\left(\mathrm{Ca}_{6} \mathrm{Al}_{2}\left(\mathrm{SO}_{4}\right)_{3}(\mathrm{OH})_{12} 26 \mathrm{H}_{2} \mathrm{O}\right)$ are the core products of corrosion when concrete is exposed to sulphuric acid reaction [14]. Ettringite is an expansive crystalline substance that may cause cracking of the attacked concrete surface [15]. Presence of microcracks in the concrete surface allows penetration of chlorides and moisture into the concrete/steel interface and hence simulates corrosion of the rebar [16]. The formed secondary gypsum further contributes to the deterioration of the hardened Portland cement paste through loss of stiffness and strength, expansion, and cracking of the concrete structure. The attacked concrete surface by the biogenic acid is transformed into a soft and pulpy noncohesive layer [17].

Presence of high humidity, low $\mathrm{pH}$, and increased porosity on the exposed concrete surface in the sewer network makes the sulphur oxidizing bacteria thrive well. This facilitates the production of more biogenic acid. The acid reacts with the soluble parts of the concrete leading to severe deterioration of the concrete structures [18]. According to Jensen, a microbial attack on concrete microstructure may reduce its expected service life to less than 100 years [19].

Even though it is a well-known fact that composite inhabitants of microorganisms flourish well in sewer setups, the recent view that links concrete corrosion chiefly to the action of bacterial production of biogenic sulphuric acid remains broadly acknowledged. While recent studies have focused primarily on the microbial deterioration of concrete structures, the effect of bacteria in providing a suitable environment for ingress of other deleterious materials into the concrete matrix has been relatively ignored. This work sought to investigate the contribution of Acidithiobacillus thiooxidans in accelerating the chloride ingress in cement mortars.

\section{Materials and Methods}

2.1. Materials. Ordinary Portland cement (OPC), CEM I $42.5 \mathrm{~N}$ and Portland pozzolana cement (PPC), CEM IV 32.5R conforming to KS EAS 18:1-2017 [20] were sampled from Savannah Cement Limited, Kenya. Standard sand manufactured in accordance with ISO 679:2009 and EN 196-1 was purchased from Xiamen ISO Standard Sand Company Limited in China. The sand was used for casting of the test mortars. Actively growing culture of Acidithiobacillus thiooxidans, DSM 14887, was purchased from German Collection of Microorganisms and Cell Cultures $\mathrm{GmbH}$, Germany. Analytical grade reagents supplied by Kobian Scientific Kenya Limited were used to prepare the bacteria medium.

\subsection{Methods}

2.2.1. Chemical Characterization of Test Cements. The X-ray fluorescence technique was used to determine the chemical composition of the test cements. PANalytical XRF equipment model Epsilon $3^{\mathrm{XLE}}$ was used in this experiment. $0.900 \mathrm{~g}$ of each test cement was accurately weighed in a platinum crucible and mixed with $9.000 \mathrm{~g}$ of lithium tetraborate as a flux. The resultant mixture was fused in an M4 gas fusion unit for a period of 17 minutes to form a glass bead. The formed glass beads were kept in a desiccator to cool before transferred into the XRF unit for analysis. Each test cement was analysed in triplicates, and the average values were tabulated as shown in Table 1 . As shown in Table 1, both test cements met all the chemical requirements in accordance with KS EAS 18:1-2017 [20].

\subsubsection{Growth of Acidithiobacillus thiooxidans.} Microbiology Laboratory of the University of Embu was used to grow the cultures of Acidithiobacillus thiooxidans. Definite masses of analytical grade reagents were used to prepare the bacteria medium as shown in Table 2. Exact quantities of $\mathrm{KH}_{2} \mathrm{PO}_{4}, \mathrm{MgSO}_{4} \cdot 7 \mathrm{H}_{2} \mathrm{O},\left(\mathrm{NH}_{4}\right)_{2} \mathrm{SO}_{4}$, and $\mathrm{CaCl}_{2} \cdot 2 \mathrm{H}_{2} \mathrm{O}$ were precisely weighed using an analytical balance model Kern AEJ and dissolved in distilled water. The volume of the total mixture was made up to 1 litre. The contents were thoroughly mixed and the $\mathrm{pH}$ was adjusted using sulphuric acid to 4.4. Autoclaving was done for a period of 15 minutes at a temperature of $121^{\circ} \mathrm{C}$. $\mathrm{Na}_{2} \mathrm{~S}_{2} \mathrm{O}_{3} \cdot 5 \mathrm{H}_{2} \mathrm{O}$ was separately sterilized by filtration and added to the resultant mixture after autoclaving. The solution was allowed to cool, and the active culture of Acidithiobacillus thiooxidans (DSM 14887) was introduced. Incubation was carried out for a period of 30 days with the temperature maintained at $27^{\circ} \mathrm{C}$. The concentration of the microbial solution was maintained at $1.0 \times 10^{7}$ cells $/ \mathrm{mL}$ using a spectrophotometer. This solution was used as mix water to cast the bacterial mortars of the test cements.

2.2.3. Casting of Test Mortars. KS EAS 148:1-2000 [21] was followed in the casting of the cement samples. $40 \mathrm{~mm} \times 40 \mathrm{~mm} \times 160 \mathrm{~mm}$ prisms of each test cements were made at the Physics Laboratory of Savannah Cement Limited, Kenya. The control samples were cast and cured in distilled water and labelled as OPC $\left(\mathrm{H}_{2} \mathrm{O}\right)$ and PPC $\left(\mathrm{H}_{2} \mathrm{O}\right)$. Distilled water used had a $\mathrm{pH}$ of 7 and conductivity of $5.5 \mu \mathrm{S} /$ $\mathrm{m}$. Bacterial prepared mortars were cast using bacterial solution as mix water and labelled as OPC (AT) and PPC (AT), respectively. In each setup, a standard water-to-cement $(\mathrm{w} / \mathrm{c})$ ratio of 0.5 was maintained. The prepared mortar prisms from each category of test cements were cured 
TABle 1: Chemical properties of test cements.

\begin{tabular}{lcc}
\hline Wt.\% composition & OPC CEM I 42.5N & PPC CEM IV 32.5R \\
\hline $\mathrm{SiO}_{2}$ & 20.45 & 33.40 \\
$\mathrm{Fe}_{2} \mathrm{O}_{3}$ & 3.25 & 5.40 \\
$\mathrm{Al}_{2} \mathrm{O}_{3}$ & 5.60 & 11.58 \\
$\mathrm{MgO}$ & 1.50 & 0.96 \\
$\mathrm{CaO}$ & 64.72 & 43.92 \\
$\mathrm{SO}$ & 2.20 & 1.92 \\
$\mathrm{~K}_{2} \mathrm{O}$ & 0.30 & 0.40 \\
$\mathrm{Na}_{2} \mathrm{O}$ & 0.18 & 0.22 \\
$\mathrm{LOI}$ & 1.80 & 2.20 \\
\hline
\end{tabular}

TAble 2: Composition for the Acidithiobacillus thiooxidans medium (DSM 14887).

\begin{tabular}{lc}
\hline Chemical reagent (AR) & Mass in grams $(\mathrm{g})$ \\
\hline $\mathrm{KH}_{2} \mathrm{PO}_{4}$ & 3.00 \\
$\mathrm{MgSO}_{4} \cdot 7 \mathrm{H}_{2} \mathrm{O}$ & 0.50 \\
$\left(\mathrm{NH}_{4}\right)_{2} \mathrm{SO}_{4}$ & 3.00 \\
$\mathrm{CaCl}_{2} \cdot 2 \mathrm{H}_{2} \mathrm{O}$ & 0.25 \\
$\mathrm{Na}_{2} \mathrm{~S}_{2} \mathrm{O}_{3} \cdot 5 \mathrm{H}_{2} \mathrm{O}$ & 5.00 \\
\hline
\end{tabular}

separately under water with temperature maintained at $25^{\circ} \mathrm{C}$ as described in KS EAS 148:1-2000 [21].

2.2.4. Scanning Electron Microscopy Analysis (SEM). The prepared test mortar prisms, OPC $\left(\mathrm{H}_{2} \mathrm{O}\right)$, PPC $\left(\mathrm{H}_{2} \mathrm{O}\right)$, OPC (AT), and PPC (AT), were subjected to SEM analysis after the $28^{\text {th }}$ day of curing at the University of Pretoria, South Africa. Preparation of test samples for SEM analysis was carried out as defined by Scrivener et al., 2017 [22]. The SEM instrument used in the analysis was Zeiss Ultra Plug FEGSEM.

2.2.5. Compressive Strength Testing. Testing of compressive strength was conducted after the $2^{\text {nd }}, 7^{\text {th }}, 28^{\text {th }}$, and $56^{\text {th }}$ days of curing using an automatic compression testing machine model YAW-300 at Savannah Cement Limited, Kenya. Triplicate samples were tested for each duration of curing and the average values were obtained. The resultant compressive strength was calculated and reported in $\mathrm{MPa}$ as described in KS EAS 148:1-2000 [21].

2.2.6. Determination of Porosity. The porosity of the bacterial and control mortar prisms was determined after 28 days of curing. The porosity was approximated using

$$
P=\left(\frac{\mathrm{Ma}-\mathrm{Mb}}{\mathrm{Ma}-\mathrm{Mc}}\right) \times 100,
$$

where $P$ is the porosity, $\mathrm{Ma}$ is the mass of the test prism in the saturated surface dry condition, $\mathrm{Mb}$ is the mass of the dry test prism until reaching constant mass in the oven, and $\mathrm{Mc}$ is the mass of the saturated test prism.
2.2.7. X-Ray Diffraction Analysis (XRD). The X-ray diffraction technique was employed in analyzing the hydrated mortars of control and microbially exposed test cements after 28 days of curing. The technique was to help identify the formation of various new crystals in both controls and microbially exposed test mortars. Each test sample of OPC $\left(\mathrm{H}_{2} \mathrm{O}\right)$, PPC $\left(\mathrm{H}_{2} \mathrm{O}\right)$, OPC (AT), and PPC (AT) were dried in an oven set at $110^{\circ} \mathrm{C}$ and then pulverized using HERZOG machine. The finely obtained powder for each sample was analysed using a Bruker D8 advance diffractometer.

2.2.8. Chloride Ingress Test. Both controls and microbial test mortar prisms were subjected to the chloride ingress test after 28 days of curing. The chloride ingress test was conducted in accordance with ASTM C 1556: 11a 2016 [23]. $500 \mathrm{~cm}^{3}$ of $3.5 \% \mathrm{NaCl}$ solution was filled in the cathode compartment, and $500 \mathrm{~cm}^{3}$ of distilled water was filled in the anode compartment of the electrochemical setup. As defined in Section 2.2.3, each test cement was exposed to the chloride ingress test for a period of 36 hours. After the exposure period, polishing of the test mortar prisms was done using a sand paper on the $40 \mathrm{~mm} \times 40 \mathrm{~mm}$ surfaces. Across the $80 \mathrm{~mm}$ length of the test prism, drilling was done at an interval of $10 \mathrm{~mm}$ using a drill bit with a radius of $15 \mathrm{~mm}$. The collected samples were dried in an electrical laboratory oven set at $105^{\circ} \mathrm{C}$ for a period of 1 hour. The samples were pulverized in a HERZOG pulverizer, and the resultant powder from each test set up was kept for chloride analysis.

2.2.9. Chloride Profiling. Chloride concentration in the test samples was determined as described in KS EAS 148-2: 2000 [24]. According to Crank, the estimation of apparent chloride diffusion coefficient was achieved under nonsteady state condition assuming boundaries $C_{(x, t)}=0$ at $t=0$, $0<x<\infty, C_{(x, t)}=C_{s}$ at $x=0,0<t<\infty$, constant effects of coexisting ions, linear chloride binding, and one-dimension diffusion into semi-infinite solid. Crank's solution to Fick's second law of diffusion is given by [25]

$$
\mathrm{C}_{(x, t)}=\mathrm{C}_{(s)}\left\{1-\operatorname{erf}\left[\frac{x}{\left(4 \mathrm{D}_{a p p} t\right)(1 / 2)}\right]\right\},
$$

where $C_{(x, t)}$ is the concentration of chloride ions at any depth $x$ in the mortar bulk at time $t, C_{s}$ is the surface concentration, and $D_{\text {app }}$ is the apparent diffusion coefficient. The error correction function, erf, is the Gaussian error function gotten from computer spreadsheets. The chloride profiles were obtained from fitting equation (2) to experimentally determined profile concentration, thus determining the values of $D_{\text {app }}$ and $C_{s}$ mathematically. Apparent diffusion coefficient $\left(D_{\text {app }}\right)$ calculated from chloride profiles is a common practice since $\mathrm{D}_{a p p}$ shows the capability of the mortar/concrete to resist chloride penetration in a natural setting. $D_{\text {app }}$ was determined using $[26,27]$

$$
D_{\text {app }}=\frac{\mathrm{RT}}{\mathrm{ZiF}} D_{\operatorname{mig}} \frac{\mathrm{Int}^{2}}{\Delta \varnothing},
$$


where $R$ is the gas constant, $\mathrm{F}$ is the Faraday constant, $T$ is the temperature of the electrolyte in $\mathrm{K}, \mathrm{Zi}$ is the valency of the ion $\mathrm{I}, \Delta \varnothing$ is the effective applied voltage in $\mathrm{V}$, and $t$ is the duration of the test/exposure in seconds.

\section{Results and Discussion}

3.1. Scanning Electron Microscopy (SEM). Figures 1-4 represent the SEM images (i), (ii), (iii), and (iv) for OPC $\left(\mathrm{H}_{2} \mathrm{O}\right)$, OPC (AT), PPC $\left(\mathrm{H}_{2} \mathrm{O}\right)$, and PPC (AT), respectively. The obtained SEM micrographs corresponded with other author's works previously published [15, 28-30]. As observed in Figure 1, there was systematic formation of calcium hydroxide $(\mathrm{CH})$ plates and calcium silicate hydrates $(\mathrm{C}-\mathrm{S}-\mathrm{H})$ in OPC $\left(\mathrm{H}_{2} \mathrm{O}\right)$ as the key hydration products [15]. This was as expected because, under normal conditions, hydration process would result in even distribution of hydration products within the pore system. The formed ettringite (AFt) in the microstructure of OPC $\left(\mathrm{H}_{2} \mathrm{O}\right)$ was attributed to gypsum added in OPC to improve its workability and regulate the setting time during mortar/concrete placement [28].

There was an enormous formation of ettringite (AFt) and attrition of calcium hydroxide $(\mathrm{CH})$ plates in OPC (AT) as shown in Figure 2. This was perhaps due to the reaction of cement constituents with the biogenic acid produced from the microbial activity. According to studies conducted by Parker, Acidithiobacillus thiooxidans produces vast amounts of sulphuric acid [31]. The formed acid would attack the tricalcium aluminate phase of the cement and form ettringite (AFt). The formed AFt is expansive and deleterious. Comparable observations have been made by other authors $[15,28,32-34]$.

As observed in Figure 3, there was a significant reduction of $\mathrm{CH}$ in the pore system of PPC $\left(\mathrm{H}_{2} \mathrm{O}\right)$. This was mainly due to reduced lime content in PPC as shown in Table 1. Additionally, pozzolanic activity lowers the $\mathrm{CH}$ content by formation of secondary hydration products (CSH and $\mathrm{CAH}$ ). This is achieved through the reaction of the active silica and alumina in pozzolana with the $\mathrm{CH}$ from the cement hydration. The observed ettringite (AFt) in the PPC $\left(\mathrm{H}_{2} \mathrm{O}\right)$ was attributed to primary gypsum added to retard the setting of cement. As shown in Figure 4, there was a noticeable increase in AFt formation in PPC (AT). This was perhaps due to the attack of biogenic acid on the cement. The formed AFt in PPC (AT) was not as extreme as observed in OPC (AT). The reduced $\mathrm{CH}$ content in PPC due to pozzolanic activity would have perhaps lowered the aggressiveness of acid attack and hence making the PPC more resistant than OPC [33].

3.2. Compressive Strength. The measured compressive strength for the test cements was presented graphically as shown in Figures 5 and 6 . The control test cements, OPC $\left(\mathrm{H}_{2} \mathrm{O}\right)$ and PPC $\left(\mathrm{H}_{2} \mathrm{O}\right)$, met the desired strength requirement at 28 days of curing as described in KS EAS 18:1-2017 [20]. PPC $\left(\mathrm{H}_{2} \mathrm{O}\right)$ exhibited the low early strengths as compared to $\mathrm{OPC}\left(\mathrm{H}_{2} \mathrm{O}\right)$. This was attributed to slow early

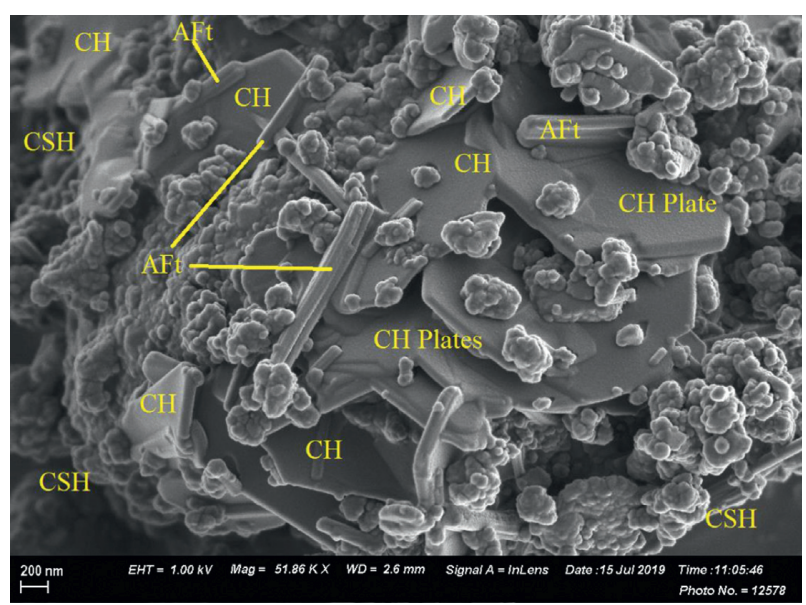

FIgure 1: SEM image (i) OPC $\left(\mathrm{H}_{2} \mathrm{O}\right)$.

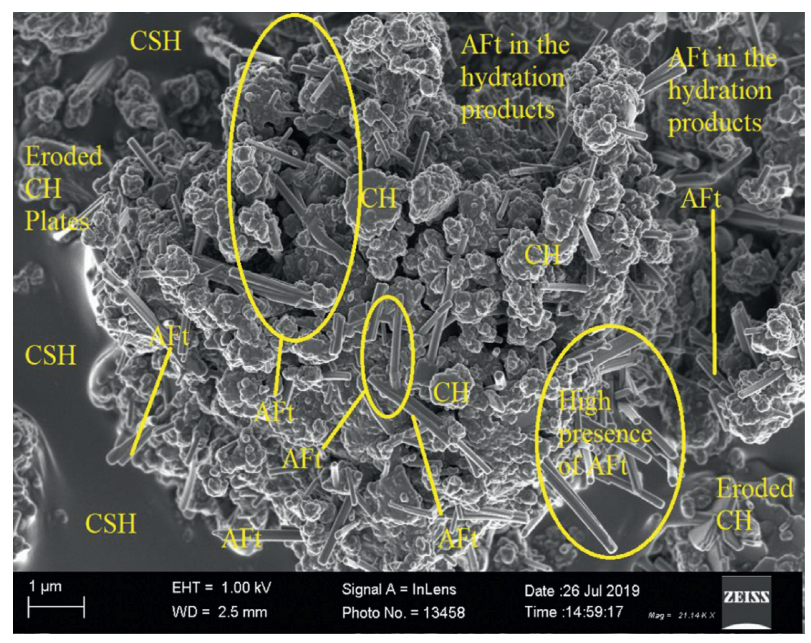

Figure 2: SEM image (ii) OPC (AT).

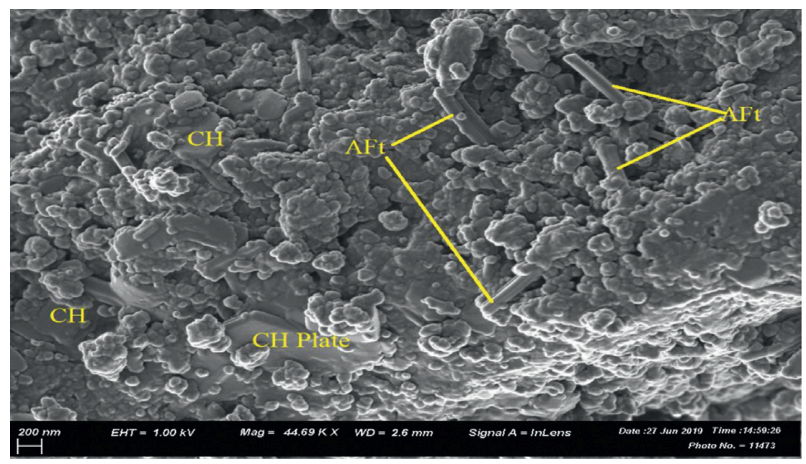

Figure 3: SEM image (iii) PPC $\left(\mathrm{H}_{2} \mathrm{O}\right)$.

hydration due to the pozzolana effect. As a result of low heat of hydration associated with pozzolanic materials, the formation of C-S-H is delayed. This contributes to low early strengths in pozzolana-based cements [35].

However, it was further observed that the strength development of the control PPC and PPC $\left(\mathrm{H}_{2} \mathrm{O}\right)$ increased significantly even after 28 days of curing. This was attributed 


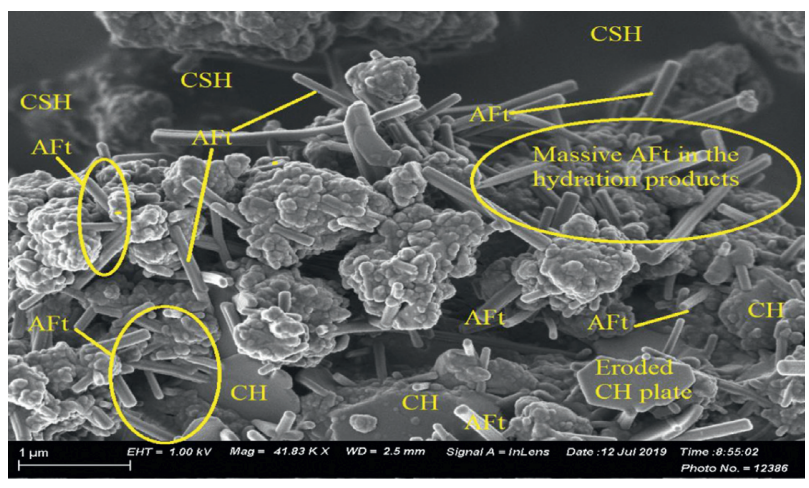

FIgURE 4: SEM image (iv) PPC (AT).

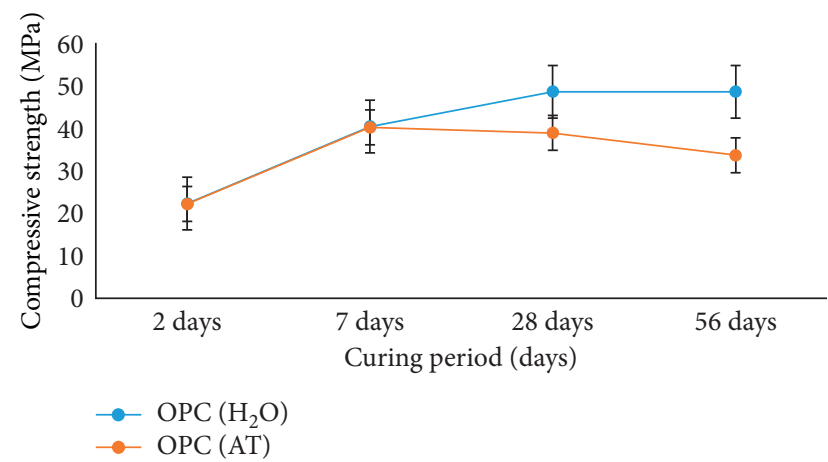

FIGURE 5: Compressive strength results for control and microbially treated OPC.

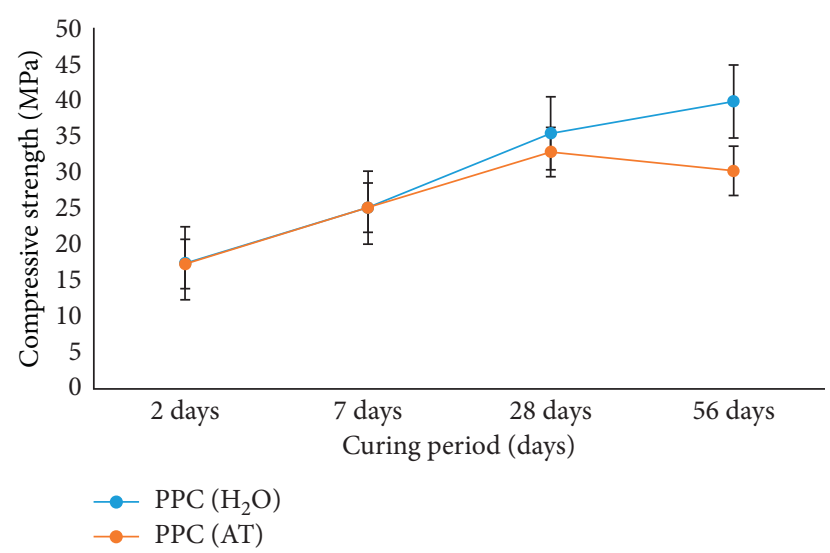

FIGURE 6: Compressive Strength results for control and microbially treated PPC.

to pozzolanic reaction. Presence of silica $\left(\mathrm{SiO}_{2}\right)$ in pozzolana further reacts with the resultant portlandite $(\mathrm{CH})$ from cement hydration to form secondary C-S-H. This promotes additional strength gain in pozzolanic-based cements [36]. High early strength in the control OPC, OPC $\left(\mathrm{H}_{2} \mathrm{O}\right)$ was attributed to the high content of $\mathrm{C}_{3} \mathrm{~A}$ and $\mathrm{C}_{3} \mathrm{~S}$ phases as compared to PPC. These cement phases are responsible for high heat of hydration and hence facilitate high early strength development. There was no observed significant increase in strength of control OPC and OPC (H2O) after 28 days. This was perhaps due to completion of hydration process.

The test mortars prepared with Acidithiobacillus thiooxidans solution as mix water and labelled as OPC (AT) and PPC (AT) exhibited similar strength trends as the control OPC and PPC at 2 and 7 days of curing. It was perhaps too early to notice the influence of the bacteria on the test mortars. At 28 days of curing, an appreciable decrease in compressive strength of $7.34 \%$ and $19.88 \%$ on PPC (AT) and OPC (AT) was realized. The strength decline increased with increase in the curing period. At 56 days of curing, PPC (AT) and OPC (AT) registered a strength decrease of $24.12 \%$ and $30.74 \%$, respectively. The observed phenomenon on reduced compressive strength in bacterial treated mortars was purely attributed to the activity of Acidithiobacillus thiooxidans.

Earlier studies conducted by Parker have shown that Acidithiobacillus thiooxidans has the ability to produce huge quantities of biogenic sulphuric acid $[12,31]$. The produced acid is destructive to the concrete/mortar. It reacts with the chief hydration product of the cement $(\mathrm{CH})$ to produce ettringite, $3 \mathrm{CaO} \cdot \mathrm{Al}_{2} \mathrm{O}_{3} \cdot 3 \mathrm{CaSO}_{4} \cdot 32 \mathrm{H}_{2} \mathrm{O}$, and gypsum, $\mathrm{CaSO}_{4} \cdot 2 \mathrm{H}_{2} \mathrm{O}$. These products are expansive and may result in cracking of the exposed cement structure [37, 38]. Although there was appreciable decrease in compressive strength for the exposed test mortars, PPC (AT) and OPC (AT), the effect was less pronounced in PPC as compared to OPC. This was attributed to pozzolanic activity. Pozzolanic activity lowers the amount of $\mathrm{CH}$ in the hydration matrix by forming secondary C-S-H which is more impermeable to attack by external media.

3.3. Porosity. The porosity of the test cements was conducted after 28 days of curing, and the test results were presented as shown in Figure 7. Whereas the control mortars, OPC $\left(\mathrm{H}_{2} \mathrm{O}\right)$ and PPC $\left(\mathrm{H}_{2} \mathrm{O}\right)$, demonstrated low porosity as compared to the microbial mortars, OPC (AT), and PPC (AT), PPC $\left(\mathrm{H}_{2} \mathrm{O}\right)$ reported a lower porosity percentage as compared to OPC $\left(\mathrm{H}_{2} \mathrm{O}\right)$. This was attributed to the pozzolana reaction. The reactive silica and alumina from pozzolana react with $\mathrm{CH}$ from the hydration of cement resulting in the formation of secondary C-S-H and CAH. The formed products make the mortar/concrete denser and impermeable and hence reduce the porosity $[36,39,40]$.

The high porosity in control OPC could be attributed to high levels of $\mathrm{CH}$ in the resultant pore solution and high heat of hydration as a result of high $\mathrm{C}_{3} \mathrm{~S}$ and $\mathrm{C}_{3} \mathrm{~A}$ phases in OPC cement. This condition results in the creation of many pores on the surface of the concrete/mortar made with OPC [41]. The resultant percentage of silica and alumina content in clinker is not sufficient enough to react with the unbound $\mathrm{CH}$ from the hydration process. The unreacted $\mathrm{CH}$ forms an appropriate sink for attack by external materials such as carbon (IV) dioxide, sulphates, and/or chlorides.

Microbially treated mortars exhibited a high percentage of porosity as compared to the controls. The high permeability content exhibited in OPC (AT) was attributed to calcium hydroxide $(\mathrm{CH})$ in the pore solution of the hydrated OPC. Presence of high $\mathrm{CH}$ content in the mortar matrix 


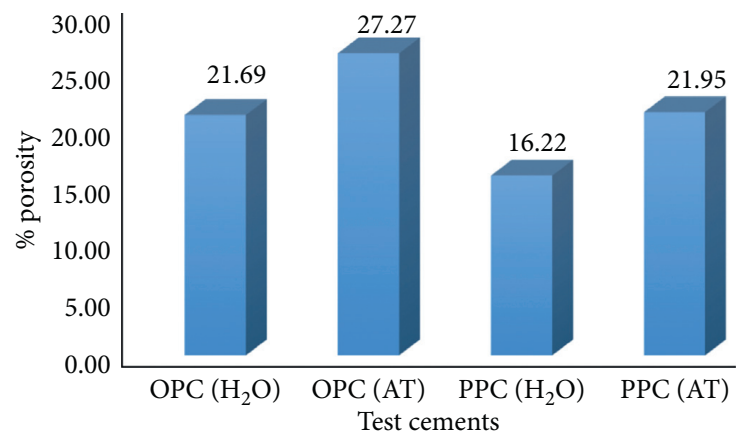

Figure 7: Porosity of control and microbial-treated test cements.

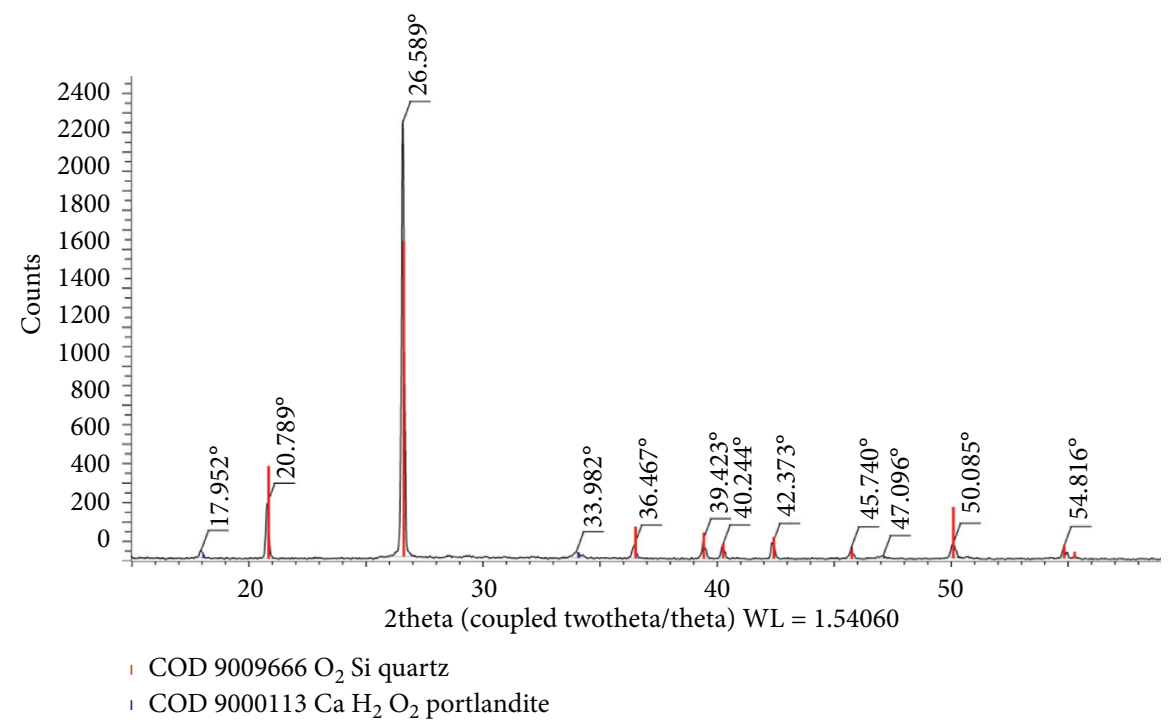

FIgURE 8: XRD diffractogram for OPC $\left(\mathrm{H}_{2} \mathrm{O}\right)$.

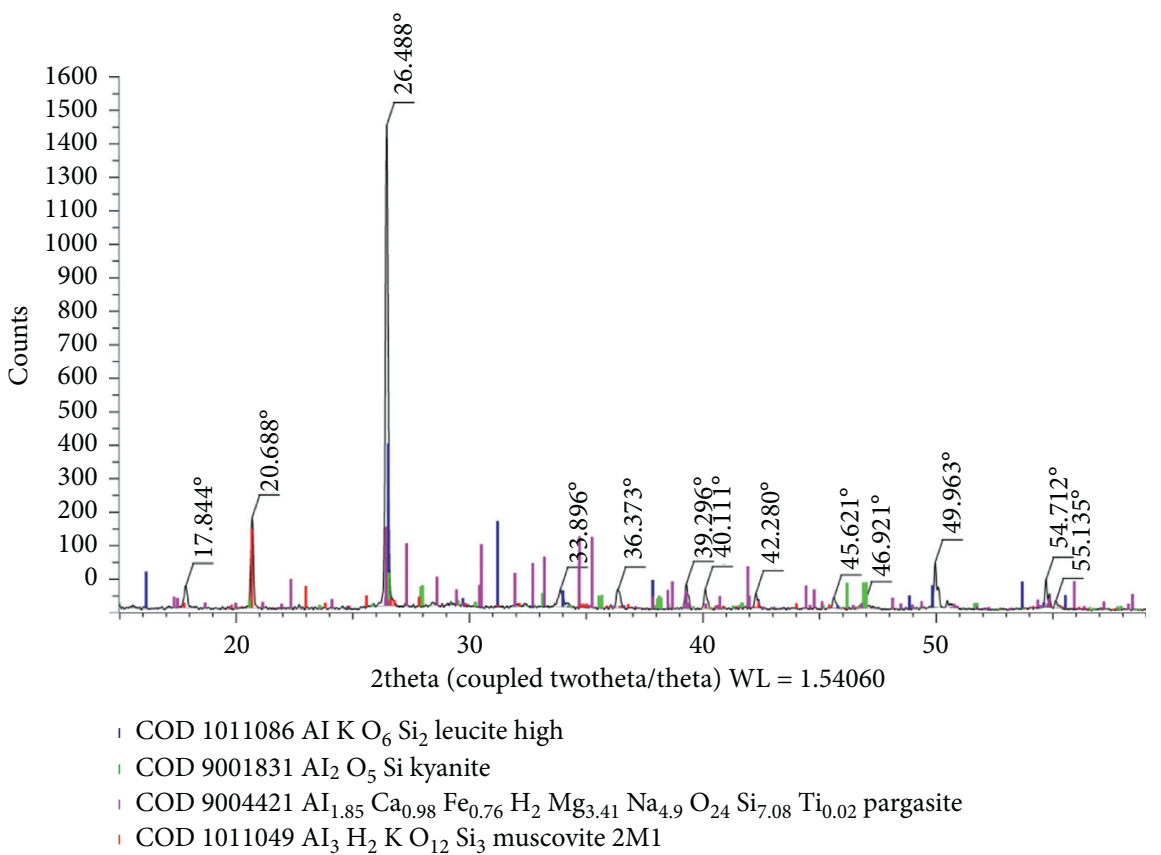

FIgURE 9: XRD diffractogram for OPC (AT). 


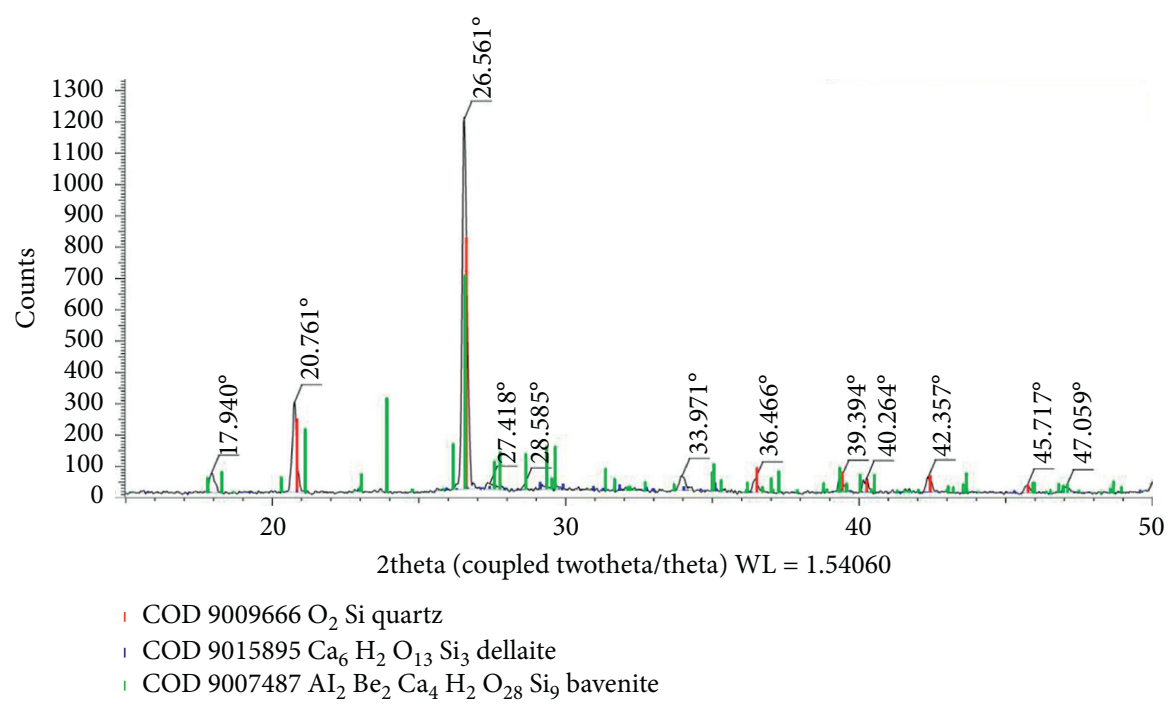

FIgURE 10: XRD diffractogram for PPC $\left(\mathrm{H}_{2} \mathrm{O}\right)$.

would perhaps provide an excellent condition for the attack by the biogenic acid. The formed products from the generated biogenic acid with $\mathrm{CH}$ are expansive and hence would result in increased pores on the mortar surface.

While PPC (AT) exhibited a significant increase in porosity, the effect was not as pronounced as observed in OPC (AT). This was perhaps due to reduced $\mathrm{CH}$ content in pozzolana-based cement (PPC). As shown in Table 1, the total content of $\mathrm{CaO}$ in PPC was low as compared to OPC and hence reduced $\mathrm{CH}$ in the hydrated PPC. This was attributed to clinker substitution in cement with pozzolana. Further, the reactive silica and alumina from pozzolana react with $\mathrm{CH}$ to form secondary $\mathrm{C}-\mathrm{S}-\mathrm{H}$ and $\mathrm{C}-\mathrm{A}-\mathrm{H}$. The formed secondary hydration products may possibly contribute to the reduction of porosity for pozzolana-based cements. Equations (4) and (5) show the pozzolanic activity that may result in additional hydration products that make the resultant pozzolanic cement mortar resistant to the ingress of external materials [28, 42].

$$
\begin{aligned}
& 2 \mathrm{SiO}_{2}+3 \mathrm{Ca}(\mathrm{OH})_{2}+5 \mathrm{H}_{2} \mathrm{O} \longrightarrow 3 \mathrm{CaO} \cdot \mathrm{SiO}_{2} \cdot 8 \mathrm{H}_{2} \mathrm{O} \\
& \mathrm{Al}_{2} \mathrm{O}_{3}+4 \mathrm{Ca}(\mathrm{OH})_{2}+9 \mathrm{H}_{2} \mathrm{O} \longrightarrow 4 \mathrm{CaO} \cdot \mathrm{Al}_{2} \mathrm{O}_{3} \cdot 13 \mathrm{H}_{2} \mathrm{O}
\end{aligned}
$$

3.4. X-Ray Diffraction (XRD) Results. The XRD results for the test mortars, OPC $\left(\mathrm{H}_{2} \mathrm{O}\right)$, OPC $(\mathrm{AT})$, PPC $\left(\mathrm{H}_{2} \mathrm{O}\right)$, and PPC (AT) are as presented in Figures 8-11, respectively. As shown, there was a significant formation of new products in microbially treated mortars. In OPC (AT), compounds such as Leucite $\left(\mathrm{AlKO}_{6} \mathrm{Si}_{2}\right)$ and Kyanite $\left(\mathrm{Al}_{2} \mathrm{O}_{5} \mathrm{Si}\right)$ were formed. $\mathrm{AlKO}_{6} \mathrm{Si}_{2}$ lowers the cement tensile strength, whereas $\mathrm{Al}_{2} \mathrm{O}_{5} \mathrm{Si}$ causes permanent expansion of the cement mortar. As observed in compressive strength results, OPC (AT) reported low strengths with high porosity. PPC (AT) on the other hand showed formation of trona $\left(\mathrm{C}_{2} \mathrm{H}_{5} \mathrm{Na}_{3} \mathrm{O}_{8}\right)$ which contributes to the strength decrease of cement mortar/ concrete. It favours the formation of a porous material. This was evident from the porosity results.

\subsection{Chloride Ingress}

3.5.1. Chloride Profiling. The profiling of chloride ion concentration in the test mortars was determined as described in Section 2.2.7. Concentration of chloride ions in the bulk of the test cement mortars was monitored at different depths of penetration. Figure 12 gives the chloride ion concentration at different depths of penetration for control and microbially treated mortars.

Generally, the chloride ion concentration decreased with increase in penetration depth in both controls and microbial mortars. This was attributed to the formation of bulk hydration products that would inhibit the ingress of chlorides. Cement-based materials have the ability to bind a certain proportion of chlorides [43]. Previous work by Cao et al. [44] showed that chloride ions can be found in calcium chloroaluminate hydrates such as Friedel's salts or Kuzel's salts. The formed salts can be adsorbed to the C-S-H phase of the hydrated cement.

The control OPC and OPC $\left(\mathrm{H}_{2} \mathrm{O}\right)$ demonstrated high chloride ingress as compared to control PPC and PPC $\left(\mathrm{H}_{2} \mathrm{O}\right)$. This was perhaps attributed to high porosity reported on control OPC. High porosity could provide an appropriate conduit for the ingress of chlorides into the mortar matrix. Reduced chloride ingress in control PPC and PPC $\left(\mathrm{H}_{2} \mathrm{O}\right)$ could have been due to pozzolana activity. Pozzolanic activity increases the binding ability of chloride ions into the mortar matrix. This is due to formation of additional C-S-H from pozzolana reaction with $\mathrm{CH}$ in cement [45]. Janotka et al. [46] reported that blended cements have a higher content of C-S-H than OPC.

Microbially treated mortars, OPC (AT) and PPC (AT), showed high chloride ingress as compared to controls. However, the chloride ingress was more prominent in OPC (AT). The activity of Acidithiobacillus thiooxidans may have 


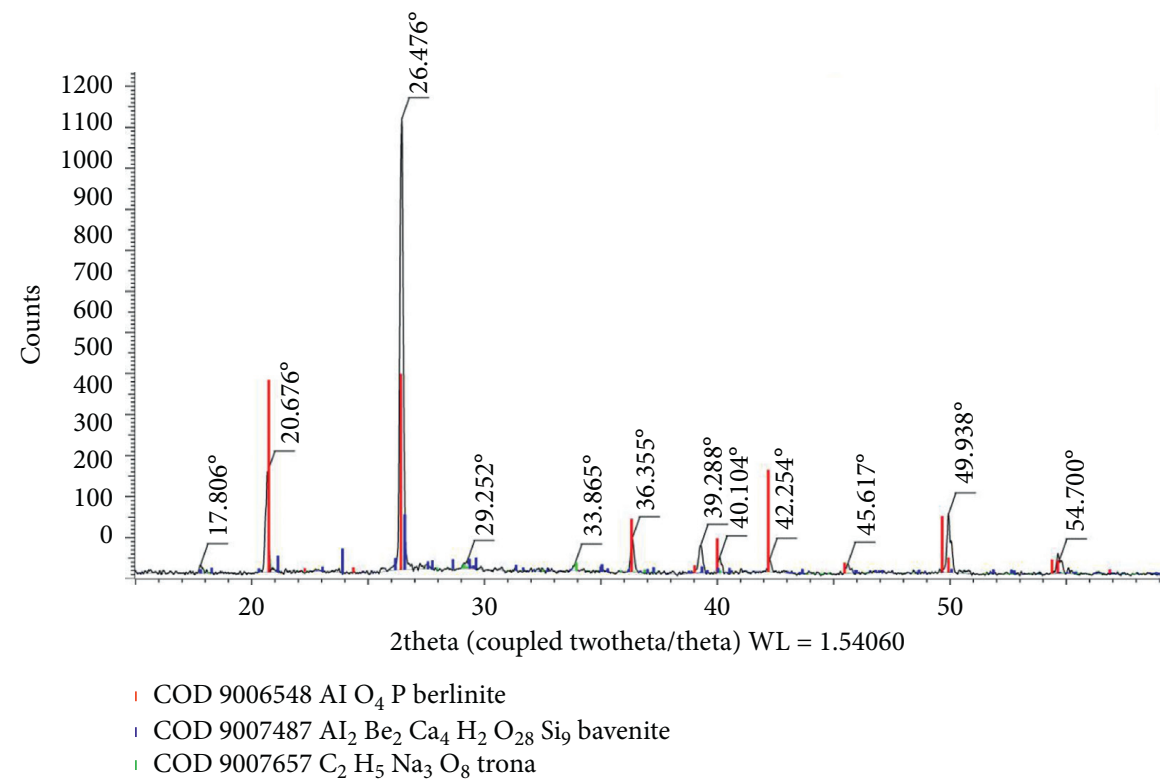

Figure 11: XRD diffractogram for PPC (AT).

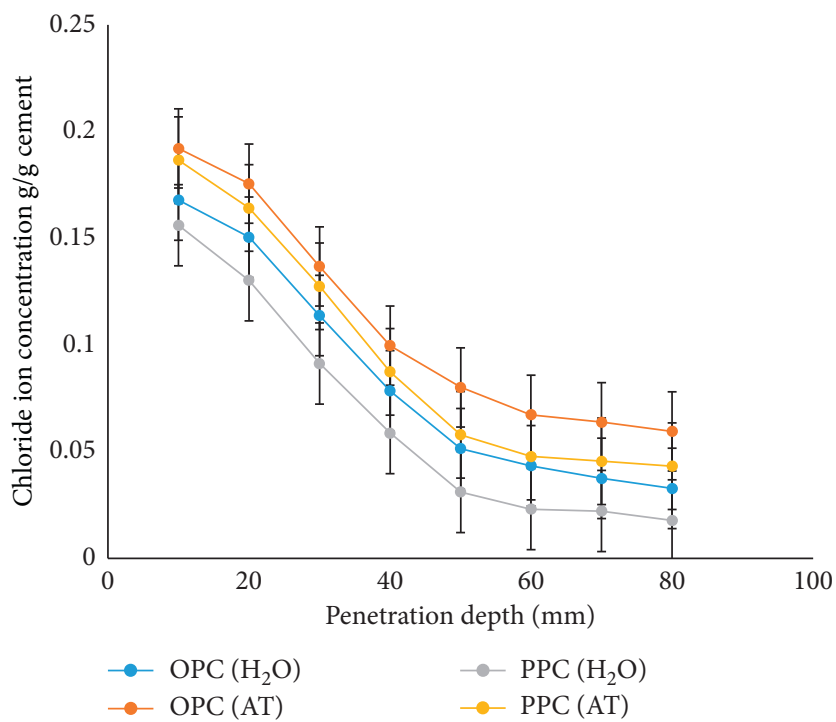

FIGURE 12: Chloride ion concentration at different depths of penetration for control and microbial exposed mortars.

TAble 3: $C_{s}, D_{\text {mig, }}, D_{\text {app }}$, and $r^{2}$ values for test mortars in $\mathrm{NaCl}$ solution.

\begin{tabular}{lcccc}
\hline Test cement sample & $C_{s}$ & $D_{\text {mig }} \times 10^{-8}\left(\mathrm{~m}^{2} / \mathrm{s}\right)$ & $D_{\text {app }}\left(\mathrm{m}^{2} / \mathrm{s}\right)$ & $r^{2}$ \\
\hline OPC $\left(\mathrm{H}_{2} \mathrm{O}\right)$ & 0.183 & 1.3764 & $6.9804 \times 10^{-10}$ & 0.197 \\
OPC $(\mathrm{AT})$ & 0.2062 & 2.3341 & $1.1837 \times 10^{-9}$ & $6.8645 \times 10^{-5}$ \\
PPC $\left(\mathrm{H}_{2} \mathrm{O}\right)$ & 0.1822 & 1.1238 & $5.6992 \times 10^{-10}$ & 0.1308 \\
PPC $(\mathrm{AT})$ & 0.194 & 1.534 & $7.7795 \times 10^{-10}$ & 0.6902 \\
\hline
\end{tabular}

accelerated the chloride ingress in OPC rather than PPC. OPC is more susceptible to the attack by acid due to high availability of $\mathrm{CH}$. PPC (AT) exhibited some resistance to bacterial activity. This was probably due to reduced porosity in PPC (AT) which was attributed to pozzolanic activity. The resultant mortar from pozzolanic-based materials is dense and less impermeable to the ingress of foreign materials such as chlorides. 
3.5.2. Chloride Apparent Diffusion Coefficient $\left(D_{a p p}\right)$. The test results for $D_{\text {app }}$ and $r^{2}$ were calculated from the chloride error function fitting curve. The attained results are tabulated as presented in Table 3. Microbially treated test mortars, OPC (AT) and PPC (AT), exhibited high apparent diffusion coefficient as compared to control test samples, $\mathrm{OPC}\left(\mathrm{H}_{2} \mathrm{O}\right)$ and PPC $\left(\mathrm{H}_{2} \mathrm{O}\right)$. OPC (AT) had the highest apparent diffusion coefficient. The bacterial activity would initiate a deleterious mechanism within the cement matrix and hence interfere with the pore system of the cement matrix. As shown earlier, high porosity would perhaps provide a conduit for chloride ingress into the mortar matrix.

The lowest $D_{\text {app }}$ was observed in control PPC, PPC $\left(\mathrm{H}_{2} \mathrm{O}\right)$. This was attributed to the ability of pozzolana-based cement to bind more chlorides as opposed to OPC. Wang et al. [47] and Kim et al. [48] in their work reported that blended cements would have low $D_{\text {app }}$ due to the formation of additional cementitious materials in the mortar/concrete matrix.

\section{Conclusion}

The results from this work indicated that Acidithiobacillus thiooxidans play a vital role in facilitating the ingress of chloride ions into the cement mortar through the promotion of increased porosity in cement mortars. Ingress of chloride ions in the mortar/concrete matrix may induce the corrosion of the rebar resulting in the decreased service life of reinforced concrete structures. Further, from the SEM results, the bacterial strain formed injurious products within the pore system of the cement mortars hence compromising on the compressive strength. This has a negative impact on the durability aspect of cement-based materials.

\section{Data Availability}

The data used to support the findings of work are available upon request from the corresponding author.

\section{Conflicts of Interest}

The authors declare that they have no conflicts of interest.

\section{Acknowledgments}

The authors wish to thank the Management of Savannah Cement Limited, Kenya, and in particular the Managing Director Mr. Ronald Ndegwa for providing test cement samples and laboratory space to carry out the mechanical and chemical testing of cements; Director of Starex (Pty), Mr. Anton Weavid, through whom the authors were able to carry out the SEM analysis at the University of Pretoria, South Africa; Ministry of Petroleum and Mining Kenya, where the XRD analysis was carried out; Laboratory of Microbiology, University of Embu, where the culturing of bacteria was done; and Kenyatta University for Facilitation of Library Materials.

\section{References}

[1] K. De Weerdt, B. Lothenbach, and M. R. Geiker, "Comparing chloride ingress from seawater and $\mathrm{NaCl}$ solution in Portland cement mortar," Cement and Concrete Research, vol. 115, pp. 80-89, 2019.

[2] C. Gunasekara, D. Law, S. Bhuiyan, S. Setunge, and L. Ward, "Chloride induced corrosion in different fly ash based geopolymer concretes," Construction and Building Materials, vol. 200, pp. 502-513, 2019.

[3] M. Alexander and M. Thomas, "Service life prediction and performance testing-current developments and practical applications," Cement and Concrete Research, vol. 78, pp. 155-164, 2015.

[4] O. Aviam, G. Bar-Nes, Y. Zeiri, and A. Sivan, "Accelerated biodegradation of cement by sulfur-oxidizing bacteria as a bioassay for evaluating immobilization of low-level," Radioactive Waste Applied and Environmental Microbiology, vol. 70, no. 10, pp. 6031-6036, 2004.

[5] W. Sand and E. Bock, "Biodeterioration of ceramic materials by biogenic acids," International Biodeterioration, vol. 27, no. 2, pp. 175-183, 1991.

[6] E. Vincke, N. Boon, and W. Verstraete, "Analysis of the microbial communities on corroded concrete sewer pipes-a case study," Applied Microbiology and Biotechnology, vol. 57, no. 5-6, pp. 776-785, 2001.

[7] D. B. Rigby, Evaluation of Technical Basis for Extended Dry Storage and Transportation of Used Nuclear Fuel, Nuclear Waste Technical Review Board, Arlington, VA, USA, 2010.

[8] L. Basheer, J. Kropp, and D. J. Cleland, "Assessment of the durability of concrete from its permeation properties: a review," Construction and Building Materials, vol. 15, no. 2-3, pp. 93-103, 2001.

[9] O. M. Munyao, J. K. Thiong'o, J. M. Wachira, D. K. Mutitu, M. Romano, and G. Murithi, "Use of bacteria in protecting the concrete structures from sulphate attack-a review," Journal of Chemical Review, vol. 1, pp. 287-299, 2019.

[10] W. M. Olmstead and H. Hamlin, "Converting portions of the Los Angeles outfall sewer into a septic tank," Engineering News and American Railway Journal, vol. XLIV, no. 19, pp. 317-318, 1900.

[11] K. Milde, W. Sand, W. Wolff, and E. Bock, "Thiobacilli of the corroded concrete walls of the hamburg sewer system," Microbiology, vol. 129, no. 5, pp. 1327-1333, 1983.

[12] C. Parker, "The corrosion of concret," Australian Journal of Experimental Biology and Medical Science, vol. 23, no. 2, pp. 81-90, 1945.

[13] T. Haile, G. Nakhla, and E. Allouche, "Evaluation of the resistance of mortars coated with silver bearing zeolite to bacteria-induced corrosion," Corrosion Science, vol. 50, no. 3 , pp. 713-720, 2008.

[14] M. W. Kiliswa, K. L. Scrivener, and M. G. Alexander, "The corrosion rate and microstructure of portland cement and calcium aluminate cement-based concrete mixtures in outfall sewers: a comparative study," Cement and Concrete Research, vol. 124, p. 105818, 2019.

[15] O. M. Munyao, J. K. Thiong'o, J. W. Muthengia et al., "Study on the effect of Thiobacillus intermedius bacteria on the physico-mechanical properties of mortars of ordinary portland cement," Heliyon, vol. 6, no. 1, Article ID e03232, 2020.

[16] S. Ahmad, "Reinforcement corrosion in concrete structures, its monitoring and service life prediction-a review," Cement and Concrete Composites, vol. 25, no. 4-5, pp. 459-471, 2003. 
[17] M. Sahmaran, "Deterioration mechanisms-chemical," in Concrete Durability, A Practical Guide to Durable Concrete Structures, M. Soutsos, Ed., Thomas Telford, London, UK, 2010.

[18] M. G. Alexander and C. Fourie, "Performance of sewer pipe concrete mixtures with portland and calcium aluminate cements subject to mineral and biogenic acid attack," Materials and Structures, vol. 44, no. 1, pp. 313-330, 2011.

[19] H. S. Jensen, "Hydrogen sulfide induced concrete corrosion of sewer networks," Aalborg University, Aalborg, Denmark, 2009.

[20] KS EAS 18-1, "Kenya standard test method for oxides specification of hydraulic cement," Kenya Bureau of Standards, Nairobi, Kenya, 2017.

[21] KS EAS 148: 1, "Kenya standard test method for determination of cement strength," Kenya Bureau of Standards, Nairobi, Kenya, 2000.

[22] K. Scrivener, R. Snellings, and B. Lothenbach, A Practical Guide To Microstructural Analysis of Cementitious Materials, CRC Press, Boca Raton, FL, USA, 1st edition, 2017.

[23] ASTM C 1556-11a, "Standard test method for determining the apparent chloride diffusion coefficient of cementitious mixtures by bulk diffusion," American Society for Testing and Materials International, West Conshohocken, PA, USA, 2016, http://www.astm.org.

[24] KS EAS 148: 2, "Kenya standard cement test methods, part 2, chemical analysis," Kenya Bureau of Standards, Nairobi, Kenya, 2000.

[25] J. Crank, The Mathematics of Diffusionpp. 160-163, Oxford University Press, New York, NY, USA, 2nd edition, 1975.

[26] E. Samson, J. Marchandl, and K. A. Snyder, "Calculation of ionic diffusion coefficients on the basis of migration test results," Materials and Structures, vol. 36, no. 257, pp. 156-165, 2003.

[27] M. Castellote, C. Andrade, and C. Alonso, "Phenomenological mass balance based model of migration tests in stationary conditions. Application to non-steady-state tests," Cement and Concrete Research, vol. 30, pp. 1885-1893, 2003.

[28] O. M. Munyao, J. K. Thiong'o, J. M. Wachira, D. K. Mutitu, and R. Mwirichia, "Influence of Starkeya novella on mechanical and microstructural properties of cement mortars," Journal of Chemistry, vol. 2020, Article ID 8212396, 9 pages, 2020.

[29] K. Vijay, M. Murmu, and S. V. Deo, "Bacteria based self healing concrete-a review," Construction and Building Materials, vol. 152, pp. 1008-1014, 2017.

[30] P. Feng, E. J. Garboczi, C. Miao, and J. W. Bullard, "Microstructural origins of cement paste degradation by external sulfate attack," Construction and Building Materials, vol. 96, pp. 391-403, 2015.

[31] C. D. Parker, "Mechanics of corrosion of concrete sewers by hydrogen sulfide," Sewage and Industrial Waste, vol. 23, pp. 1477-1485, 1951.

[32] J. Sumit, G. Shweta, M. Abhijit, and M. R. Sudhakara, "Protection of concrete structures under sulphate environments by using calcifying bacteria," Construction and Building Materials, vol. 209, pp. 156-166, 2019.

[33] T. Aye and C. T. Oguchi, "Resistance of plain and blended cement mortars exposed to severe sulfate attacks," Construction and Building Materials, vol. 25, no. 6, pp. 2988-2996, 2011.

[34] T. Gutberlet, H. Hilbig, and R. E. Beddoe, "Acid attack on hydrated cement-effect of mineral acids on the degradation process," Cement and Concrete Research, vol. 74, pp. 35-43, 2015.

[35] A. M. Zeyad, B. A. Tayeh, A. M. Saba, and M. A. M. Johari, "Workability, setting time and strength of high-strength concrete containing high volume of palm oil fuel ash," The Open Civil Engineering Journal, vol. 12, no. 1, pp. 35-46, 2018.

[36] O. M. Munyao, "Effects of surface and subsurface mixing water of Nairobi, Machakos and Kajiado counties on cement mortar performance," M.Sc. thesis, Department of Chemistry, Kenyatta University, Nairobi, Kenya, 2015.

[37] T. Mori, T. Nonaka, K. Tazaki, M. Koga, Y. Hikosaka, and S. Noda, "Interactions of nutrients, moisture and $\mathrm{pH}$ on microbial corrosion of concrete sewer pipes," Water Research, vol. 26, no. 1, pp. 29-37, 1992.

[38] J. A. Redner, R. P. His, and E. J. Esfandi, "Evaluating coatings for concrete in waste water facilities: an update," Journal of Protective Coating and Linings, vol. 11, no. 12, pp. 51-61, 1994.

[39] J. Sarfo-Ansah, E. Atiemo, K. A. Boakye, D. Adjei, and A. A. Adjaottor, "Calcined clay pozzolan as an admixture to mitigate the alkali-silica reaction in concrete," Journal of Materials Science and Chemical Engineering, vol. 2, no. 5, pp. 20-26, 2014.

[40] S. A. Abo-El-Enein, M. S. Amin, F. I. El-Hosiny, S. Hanafi, T. M. ElSokkary, and M. M. Hazem, "Pozzolanic and hydraulic activity of nano-metakaolin," HBRC Journal, vol. 10, no. 1, pp. 64-72, 2014.

[41] A. Tironi, M. A. Trezza, A. N. Scian, and E. F. Irassar, "Incorporation of calcined clays in mortars: porous structure and compressive strength," Procedia Materials Science, vol. 1, pp. 366-373, 2012.

[42] K. O. Ampadu and K. Torii, "Chloride ingress and steel corrosion in cement mortars incorporating low-quality fly ashes," Cement and Concrete Research, vol. 32, no. 6, pp. 893-901, 2002.

[43] M. V. A. Florea and H. J. H. Brouwers, "Chloride binding related to hydration products," Cement and Concrete Research, vol. 42, no. 2, pp. 282-290, 2012.

[44] Y. Cao, L. Guo, and B. Chen, "Influence of sulfate on the chloride diffusion mechanism in mortar," Construction and Building Materials, vol. 197, pp. 398-405, 2019.

[45] M. Karim, M. Hossain, M. Khan, M. Zain, M. Jamil, and F. Lai, "On the utilization of pozzolanic wastes as an alternative resource of cement," Materials, vol. 7, no. 12, pp. 7809-7827, 2014.

[46] I. Janotka, L. Krajci, P. Uhli'k, and M. Bacuvci'k, "Natural and calcined clay diatomite as cement replacement materials: microstructure and pore structure study," International Journal of Research in Engineering and Technology, vol. 3, pp. 20-26, 2014.

[47] J. Wang, P. M. Basheer, S. V. Nanukuttan, and Y. Bai, "Influence of compressive loading on chloride ingress through concrete," in Proceedings of the Civil Engineering Research Association of Ireland (CERAI), Belfast, Ireland, August 2014.

[48] D. H. Kim, K. Shimura, and T. Horiguchi, "Effect of tensile loading on chloride penetration of concrete mixed with granulated blast furnace slag," Journal of Advanced Concrete Technology, vol. 8, no. 1, pp. 27-34, 2010. 